\begin{tabular}{|l|}
\hline 2. To: (Receiving Organization) \\
SST Retrieval Engineering \\
\hline 5. Proj./Prog./Dept./Div.: \\
W-320 \\
\hline
\end{tabular}

3. From: Coriginating Organization)
SST Retrieval Engineering
6. Design Authority/ Design Agent/cog.
Engr.:
J. W. Bailey /J. R. Bellomy

8. Originator Remarks:

Supporting Document Approval and Initial Release
4. Related EDT No.:

610559

7. Purchase order No.:

$\mathrm{N} / \mathrm{A}$

9. Equip./Component No.: AY \& C- Farm Electrical 10. Systen/Bldg./Facility: 241-C-106

11. Receiver Remarks: 11A. Design Baseline Document? [X] Yes [] No
12. Major Assm. Dwg. No.: $\mathrm{H}-2-820748$, sht $1 \& 2$, $\mathrm{H}-2-820751$, sht 1

13. Permit/Permit Application No.: $N / A$

14. Required Response Date: $N / A$

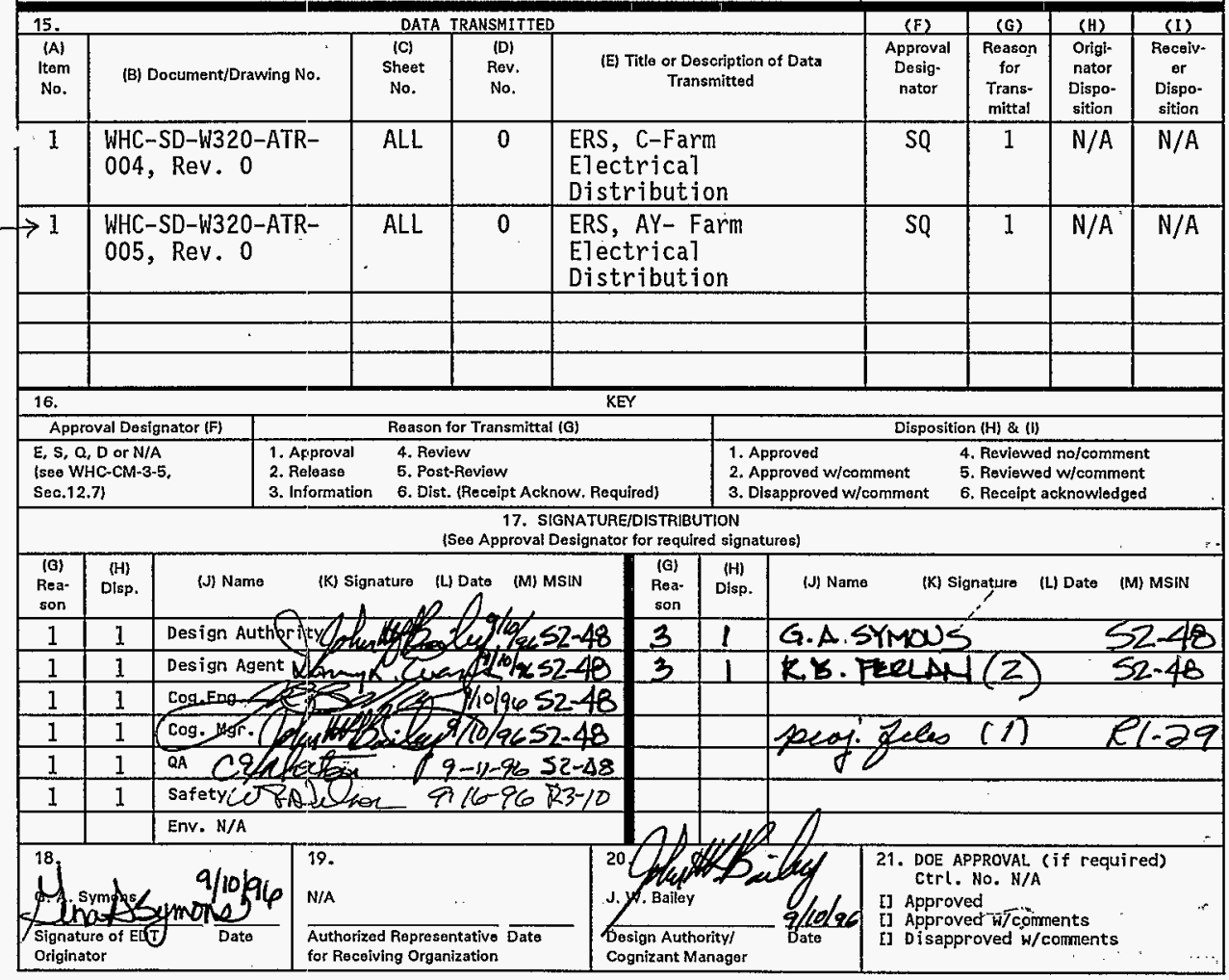

BD-7400-172-2 (05/96) GEF097 


\section{ERS, AY-Farm Electrical Distribution}

G.A. Symons

WHC, Richland, WA 99352

U.S. Department of Energy Contract DE-AC06-87RL10930
EDT/ECN: 610559
Org Code: 73530
UC: 510
B\&R Code: EW3130010
Charge Code: D2MP6
Total Pages: 23

Key Words: 241-C-106, AY-Farm Electrical Distribution, Equipment Removal System, Project $W-320$

Abstract: Project $W-320$ Acceptance Test Report for ERS, AY-Farm Electrical Distribution.

TRADEMARK DISCLAIMER. Reference herein to any specific commercial product, process, or service by trade name, trademark, manufacturer, or otherwise, does not necessarily constitute or imply its endorsement, recomendation, or favoring by the United States Government or any agency thereof or

$i$ ts contractors or subcontractors.

Printed in the United States of America. To obtain copies of this document, contact: WHC/BCS

Document Control Services, P.o. Box 1970, Mailstop H6-08, Richland WA 99352, Phone (509) 372-2420; Fax (509) 376-4989.
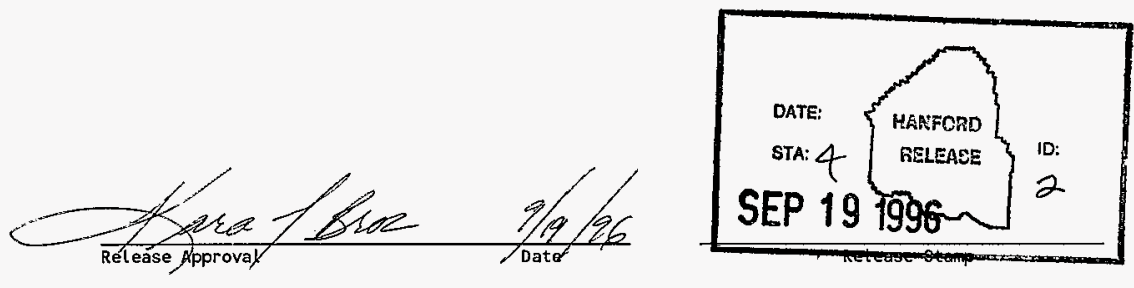

\section{Approved for Public Release}


ACCEPTANCE TEST PROCEDURE WHC-SD-W320-ATP-005

TEST TITLE ERS, AY-Farm Electrical Distribution

LOCATION AY-Farm

PROJECT NUMBER $W-320$

WORK ORDER ER6159

PROJECT TITLE W-320 Equipment Removal System

Prepared By

ICF Kaiser Hanford Company

Richland, Washington

For Westinghouse Hanford Company

Subcontract WHC-380393

PROCEDURE APPROVAL

ICF KAISER HANFORD COMPANY (ICF KH)

Daniel E. Larson.

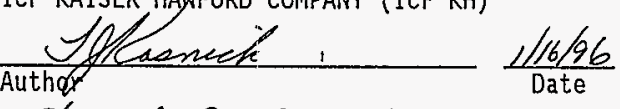

thanelge Int

Environmental
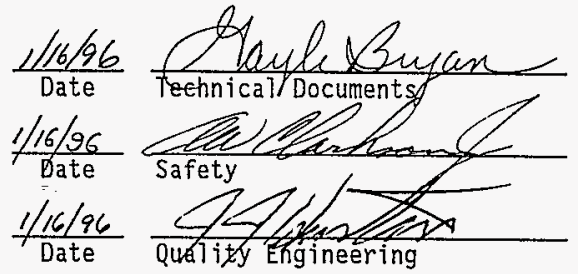

$\frac{4-12-96}{\text { Date }}$

Enumulully

Project Management

$1 / 16 / 96$ $\frac{\text { nelese }}{\text { Date }}$ $\frac{1-1 z-96}{\text { Date }}$ $\frac{16-86}{\text { Date }}$

Westinghouse Hanford Company (WHC)
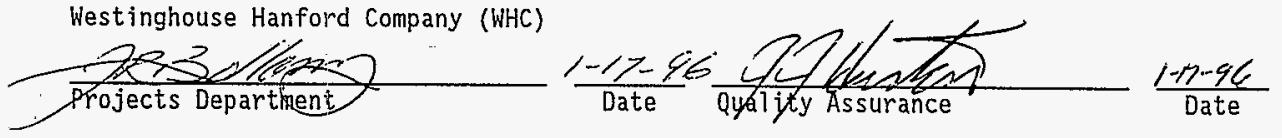

$\frac{N / A}{\text { Safety }}$

$\frac{T+S C}{\text { Date }} \frac{1.17 .96}{\text { Date }}$


$\frac{\text { EXECUTED BY }}{\text { TeEt Director/Orgatizat WATH }}$

$\frac{\text { Foud Saratives }}{\text { Recorder/organization }} \frac{8 / 3 / 51}{\text { Date }}$

Pranlantecraqu 8-3-96 harlar Pbeson las

Test Operator/Organization

Date

\section{WITNESSES}

JefE KISSEL/Wit Affhent

N/A

Witness/Organization

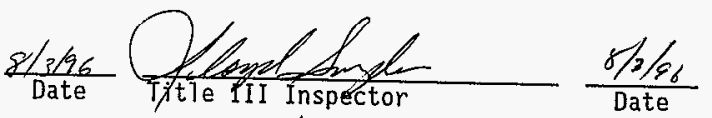

$N / A$

Date Witness/Organization

Date

A-E APPROVAL

ICF Kaiser Hanford Company (ICF KH)

Without

exceptions

Acalfiertance

Damulully

Project Marager
With exceptions resolved

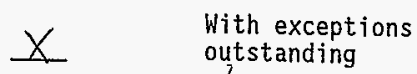

With exceptions outstanding

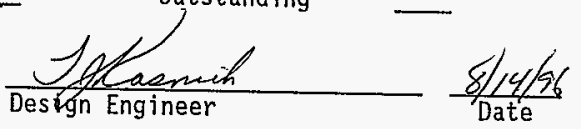

TEST APPROVAL AND ACCEPTANCE

Westinghouse Hanford Company

Without

exceptions
With exceptions resolved
With exceptions

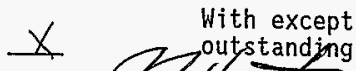

4tif $\overline{8-19-96}$

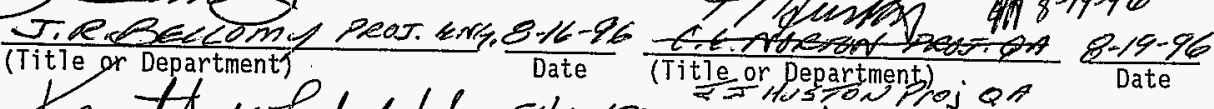

(Temett w is or Department) Y.Ro or Department) DAnAlige $\frac{8 / 16}{\text { Date }}$
Nis

(Title or Department)

Date

W320005.ATP. 2701.

$-2-$ ANR 9 QS/10/96
WHC-SD-W320-ATP-005
Rev 0
$01 / 12 / 96$ 
Section

TITLE/PROCEDURE APPROVAL

EXECUTION AND TEST APPROVAL

TABLE OF CONTENTS

PURPOSE

REFERENCES

2

RESPONSIBII_ITIES

4

3

CHANGE CONTROL

4

4

EXECUTION

EXCEPTIONS

6

PREREQUISITES, EQUIPMENT/INSTRUMENTS, AND ABBREVIATIONS

NOTE: At completion of test, enter pages added during performance of test to this Table of contents. 
$1 \cdot$ PURPOSE

This Acceptance Test Procedure (ATP) has been prepared to demonstrate that the AY-Farm Electrical Distribution, in the Equipment Removal System portion of Project $W-320$, functions as required by the design criteria.

$2 \cdot$ REFERENCES

2.1 DRAWINGS

H-2-820751, Sin 1, Rev 0 Electrical AY-Farm One Line Diagram (including EClss W-320-69, 70,102 , and 114)

2.2 SPECIFICATIONS

Construction Specification W-320-C2

2.3 ENGINEERING CHANGE NOTICES (ECNS)

Prior to final test approval, markup the controlled copy of this ATP with all of the ECNs written against it.

3 RESPONSIBILITIES

3.1 GENERAL

Each company or organization participating in this ATP will designate personne] to assume the responsibilities and duties as defined herein for their respective roles. The designees shall become familiar with this ATP and the systems involved to the extent that they can perform their assigned duties.

3.2 WHC PROJECT ENGINEER

3.2.1 Signs Execution and Test Approval page when test is complete and accepted.

3.2.2 Provides a distribution list for the approved and accepted ATP.

3.3 ICF KH PROJECT MANAGER

3.3.1 Designates a Test Director.

3.3.2 Signs Execution and Test Approval page when test is complete and accepted.

3.3.3 Signs exception form when all exceptions have been resolved.

3.4 TEST DIRECTOR

3.4.1 Coordinates and directs acceptance testing.

3.4.2 Coordinates testing with ICF KH Utilities.

3.4.3 Coordinates testing with ICF KH Craft.

$A T R$ $W H C-S D-W 320-A F P=005$ 
3.4.4 Distributes the approved testing schedule, to ICF KH Project Manager and WHC Project Engineer, before start of testing.

3.4.5 Notifjes concerned parties (includes ICF KH Project Manager, ICF KH Lead Electrical Engineer, and WHC Project Engineer) when a change is made in the testing schedule.

3.4.6 Schedules and conducts a pretest kickoff meeting with test participants when necessary.

3.4.7 Confirms that field testing and inspection of the system or portion of the system to be tested has been completed.

3.4.8 Stops any test which, in his or her judgement, may cause damage to the system until the problem has been resolved.

3.4.9 After verifying there is no adverse impact, may alter the sequence in which systems or subsystems are tested.

3.4.10 If a test is to be suspended for a period of time, ensures that the system is left in a safe mode.

3.4.11 Before restarting suspended test, reverifies the test prerequisites.

3.4.12 Initiates ECNs to document required changes to the ATP.

3.4.13 Reviews recorded data, discrepancies, and exceptions.

3.4.14 Signs Execution and Test Approval page when test has been performed.

3.4.15 Takes necessary actions to clear exceptions to the test, and signs exception form when exceptions have been resolved.

3.4.16 Obtains required signatures on the ATP Master before reproduction and distribution.

3.5 WITNESSES (Provided by Participating Organizations. One witness shall be a TitTe III acceptance inspector.)

3.5.1 Witnesses the tests.

3.5.2 Reviews results of testing.

3.5.3 Assists the Test Director when requested.

3.5.4 Signs Execution and Test Approval page when test has been performed.

3.5.5 Signs exception form when exception has been resolved.

3.6 RECORDER (Provided by ICF KH)

3.6.1 Prepares a field copy from the ATP Master.

3.6.2 Records names of all designated personnel on field copy of ATP before start of testing. 
3.6.3 Records test instrument identification numbers and calibration expiration dates, as required.

3.6.4 Initials and dates every test step on the field copy as it is completed next to the step number or on a Data Sheet, when provided. Records test data.

3.6.5 Records exceptions on an exception form. Uses additional exception forms as needed. Notifies the Test Director at time the exception is made.

3.6.6 Signs Execution and Test Approval page when test has been performed.

3.6.7 After test is finished, assigns alphanumeric page numbers to added data sheets and exception forms. Records page numbers in the Table. of contents.

3.6.8 Transfers field copy entries for each step to the Master in ink or type, signs, and dates. Transmits the completed Master to the Test Director for approval signature routing. Transmits the field copy to Construction Document Control for inclusion in the official project file.

3.6.9 Signs exception form when exception has been resolved and transmits to Test Director.

\subsection{TEST OPERATOR}

3.7.1 Performs test under direction of the Test Director.

3.7.2 Provides labor, equipment, and test instruments required for performing tests which have not been designated as being provided by others.

3.7.3 Confirms that all equipment required for performing test will be available at the start of testing.

3.7.4 Signs the Execution and Test Approval page.

3.8 A-E ACCEPTANCE INSPECTION, DESIGN ENGINEER, AND PROJECT MANAGER

3.8.1 Evaluates results.

3.8.2 Signs for A-E Approval on Execution and Test Approval page.

4 CHANGE CONTROL

Required changes to this ATP must be processed on ECNs in accordance with company procedures. If a need for change is discovered in the course of running the test, the test shall be stopped unt $i$ the $E C N$ is approved.

However, this does not prevent the running of another portion of the test unaffected by the change.

GAS $9 / 10 / 96$

W320005.ATP.2701 - - -

WHC-SD-W320-ATR-005

Rev 0

$01 / 12 / 96$ 
$\cdot 5 \cdot$ EXECUTION

5.1 OCCUPATIONAL SAFETY AND HEALTH

Individuals shall carry out their assigned work in a safe manner to protect themselves and others from undue hazards and to prevent damage to property and environment. Facility line managers shall assure the safety of activities within their areas to prevent injury, property damage, or interruption of operation. Performance of test activities shall always include safety and health aspects.

These tests involve working near energized equipment; al1 procedura1 requirements for working near energized equipment shall be followed.

5.2 PERFORMANCE

5.2.1 Conduct testing in accordance with ICF KH Procedure CON 3.5 (Performance and Recording of Acceptance Test Procedures).

5.2.2 Perform test following the steps and requirements of this procedure.

5.2.3 As aach step in Sections 7, 8, and 9 are completed, the person completing the step shall initial and date in the space provided.

6 EXCEPTIONS

6.1 GENERAL

Exceptions to the required test results are sequentially numbered and recorded on individual exception forms (KEH-428). This enables case-by-case resolution and approval of each exception.

Errors/exceptions in the ATP itself shall NOT be processed as test exceptions (see Section 4 CHANGE CONTROL).

6.2 RECORDING

6.2.1 Number each exception sequentially as it occurs and record it on an exception form.

6.2.2 Enter name and organization of the individual that identifies each exception.

6.2.3 Enter planned action to resolve each exception when such determination is made.

6.3 RETEST/RESOLUTION

Record the action taken to resolve each exception. Action taken may not be the same as planned action.

6.3.1 When action taken results in an acceptable retest, sign and date Retest Execution and Acceptance section of the exception form.

6.3.2 When action taken does not involve an acceptable retest, strike out the Retest Execution and Acceptance section of the exception form.

W320005.ATP.2701

WHC-SD-W320-ATR-005 
The Test Director provides final approval and acceptance of exceptions by checking one of the following on exception form:

6.4.1 Retest Approved and Accepted: Applicable when Retest Execution and Acceptance section is completed.

6.4.2 Exception Accepted-As-Is: Requires detailed explanation.

\subsubsection{Other: Requires detailed explanation.}

The Test Director signs and dates the exception form and obtains other approvals, if required.

\subsection{DISTRIBUTION}

A copy of the approved exception form is distributed to each participant. The signed original is attached to the ATP Master.

7 PREREQUISITES, EQUIPMENT/INSTRUMENTS, AND ABBREVIATIONS

\subsection{PREREQUISITES}

The following conditions shall exist at start of testing for that portion of the system being tested.

7.1.1 WHC Project Engineer has been notified prior to start of the testing.

7.1.2 Systems have been inspected for compliance with construction documents.

7.1.3 Reference documents (including this ATP) have been verified for correct revision number and outstanding ECNs.

A Prejob Safety Analysis has been prepared and a Prejob Safety Meeting has been conducted.

7.1.5 Test instruments have a valid calibration stamp attached. Test instrument identification numbers and calibration expiration dates have been recorded in Step 7.2 .

\section{$18 / 2 / 16 \quad 7.1 .6$}

Power Distribution Pane1 (AY-PDP-1) circuit breakers have been $18 / 2 / 91.1 .7$ continuity tested.

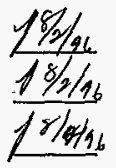

Wiring for the entire system has been continuity tested, meggered, and hy-potted, as applicable.

Grounding has been visually inspected and continuity tested.

AI1 circuit breakers on AY-PDP-I are open (OFF position).

The reriat service conductors for SER thes connected to the pole-mounted transformer bank.

Power is available on the $13.8 \mathrm{kV}$ lines. 
All worker safety equipment required to perform test is readily available.

7.2 EQUIPMENT/INSTRUMENTS

Supplied by Test Operator unless otherwise noted.

7.2.1 Volt-ohmmeters (VOM): $120 / 240$ to $277 / 480 \mathrm{~V}$

Instrument No.

Expiration Date $7 / 26 / 97$

7.2.2 Anmeters: $0-10$ amp (Low amperes anticipated since no 10ad.)

Instrument No. 0199 Expiration Date $1 / 24 / 9 ?$

7.2.3 Phase Rotation Meter

7.3 ABBREVIATIONS
A
A phase voltage or current
B B phase voltage or current
C C phase voltage or current
CB Circuit Breaker
CT Current Transformer
ECN Engineering Change Notice
EES Electrical Equipment Skid - Building 241-AY-51
ERS Equipment Removal System
GND/G Ground or Ground Bus
H $\quad 120 \mathrm{~V}$ Hot Leg
HPPT High Pressure Pump Trailer
IT Instrument Trailer
L1 First $120 \mathrm{~V}$ Hot Leg
L2 Second $120 \mathrm{~V}$ Hot Leg
PDP Power Distribution Panel AY-PDP-1
PT Potential Transformer
SBT Strong Back Trailer
VOM Volt-ohmmeter

18/a//447.1.13 The following breakers are Locked and Tagged open (OFF position):

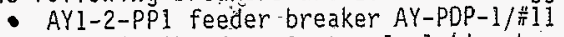

- Seismic Shutdown System Isolation breaker AY-SSS-CB ECN for

W320005.ATP. 2701 
8* $\because \quad$ EQUIPMENT REMOVAL SYSTEM - AY-FARM ELECTRICAL TESTS

\subsection{PREPARATION}

8.1.1 Verify prerequisites of Step 7.I have been met.

\section{2}

\section{CIRCUIT BREAKER SETTINGS}

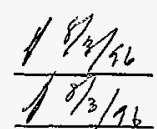

The following steps will establish the settings for the Main Disconnect breaker and the Electrical Equipment Skid - Building 24l-AY-51 feeder breaker.

8.2.1 Verify that the Main Disconnect breaker has a 600 amp trip unit.

8.2.2 Verify that the Main Disconnect breaker has all 3 short time delay pickups set at $7 \times I_{n}$.

8.2.3 Verify that the Electrical Equipment Skid - Building 241-AY-51 feeder breaker has a 600 amp trip unit.

$98 / 3 / 96$

8.2.4 Verify that the Electrical Equipment Skid - Building 241-AY-51 feeder breaker has all 3 short time delay pickups set at $5 \times I_{n}$.

\subsection{IQ DATA SETTINGS}

$\frac{18 / 3 / 96}{18 / 3 / 96}$

Remove plastic cover from backside of IQ Data metering module.

8.3.2 Locate the voltage selection block to the left of center of the unit.

$18 / 3 / 16$

8.3 .3

Set jumpers on pins identified as $460 / 575 \mathrm{~V}$.

y $8 / 3 \%$

8.3.4 Locate the 2 field selectable DIP switches to the upper right corner of the module. The 2 DIP switches have 8 switches which may be positioned. Position these DIP switches as follows:

\begin{tabular}{|c|c|}
\hline SWITCH 1 & SWITCH 2 \\
\hline SW $1-$ OFF & SW $1-$ ON \\
\hline SW $2-$ ON & SW $2-$ ON \\
\hline SW $3-$ ON & SW $3-$ ON \\
\hline SW $4-$ OFF & SW $4-$ ON \\
\hline SW $5-$ ON & SW $5-$ UNUSED \\
\hline SW 6-UNUSED & SW 6 - UNUSED \\
\hline SW $7-$ UNUSED & SW $7-$ UNUSED \\
\hline SW $8-$ ON & SW $8-$ OFF \\
\hline
\end{tabular}




\subsubsection{Reinstall the plastic cover.}

CAUTION: Observe proper electrical safety precautions around energized equipment.

8.4 MEASUREMENTS - PHASE ROTATION and VOLTAGE

8.4.1 Connect the phase rotation meter at the output of the Electrical Equipment Skid - Building 24I-AY-51 feeder breaker.
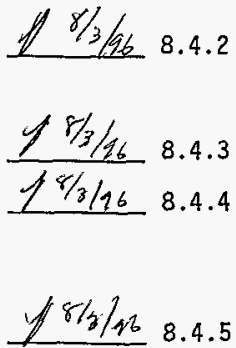

8.4 .5

$18 / 3 / 42 \quad 8.4 .6$

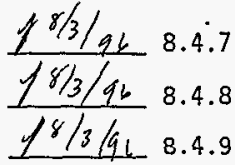

$\not 18 / 3$ /q 8.4 .10

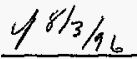

8.4.11

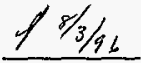

8.4 .12

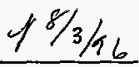

8.4 .13

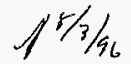

8.4 .14

8.4 .15
Place the two instrumentation disconnect switches (handles are red and round), one for the IQ DATA metering unit and one for the voltage transducer, to the oN position.

Close the Main Disconnect breaker (ON position).

Using the VOM, measure all 3 phase-to-phase voltages from the secondary of the potential transformers; measurements can be made at the input terminals of the transducer. Record results on the Data Sheet.

If any of the voltages in the previous step are not within the range of 120 to $127.5 \mathrm{~V}$, stop the test and notify the Test Director.

Test the Main Disconnect breaker using the red test pushbutton on the trip unit. If the circuit breaker does not trip, stop the test and notify the Test Director.

Place the voltage transducer disconnect switch to the OFF position.

Reset and close the Main Disconnect breaker (ON position).

close the Electrical Equipment Skid - Building 241-AY-51 feeder breaker (ON position).

Using the phase rotation meter, verify that the phase rotation corresponds to the Hanford standard, clockwise rotation for $A, B, C$. If not, stop the test and notify the Test Director.

Test the Electrical Equipment Skid - Building 241-AY-51 feeder breaker using the red test pushbutton on the trip unit. If the circuit breaker does not trip, stop the test and notify the Test Director.

With the Electrical Equipment Skid - Building 241-AY-51 feeder breaker open (OFF position), disconnect the phase rotation meter.

Reset and close the Electrical Equipment Skid - Building 241-AY-51 feeder breaker (ON position).

Switch the IQ Data unit to display $V_{A B}, V_{B C}$, and $V_{C A}$. Record the displayed values on the Data Sheet.

Using the VOM on the load side of the Electrical Equipment Skid Building 241-AY-51 feeder breaker, measure and record the values of $V_{A B}, V_{B C}$, and $V_{C A}$ on the Data Sheet. 
EXCETION

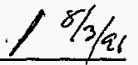

8.4 .17

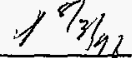

8.4 .18

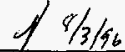

8.4 .19

$18 / 3 / 26$

8.4 .20
Verify that the voltages in the preceding two steps are in the range of 480 to $510 \mathrm{~V}$. If not, stop the test and notify the Test Director.

Switch the IQ Data unit to record $V_{A N}, V_{B N}$, and $V_{C N}$. Record the displayed values on the Data Sheet.

Using the VOM on the load side of the Electrical Equipment Skid Building 241-AY-51 feeder breaker, measure and record the values of $V_{A N}, V_{S N}$, and $V_{C N}$ on the Data Sheet.

Verify that the voltages in the preceding 2 steps are in the range of 277 to $295 \mathrm{~V}$. If not, stop the test and notify the Test Director.

Open the Electrical Equipment Skid - Building 241-AY-5I feeder breaker (OFF position).
8.5

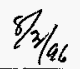

if $1 / 3 / 24$

8.5 .2

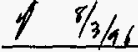

8.5 .3

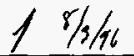

8.5 .4

$18 / 3 / 16-8.5 .5$

\section{MEASUREMENTS -- PHASE CURRENTS}

NOTE: $\quad$ Since there are no loads applied to the PDP, values of current in the following steps are expected to be 0 .

Place the clamp-on ammeter to measure the current flowing in the A phase to the Main Disconnect breaker. Record the value on the Data Sheet.

Place the clamp-on ammeter to measure the current flowing in the $B$ phase to the Main Disconnect breaker. Record the value on the Data Sheet.

Place the clamp-on ammeter to measure the current flowing in the $C$ phase to the Main Disconnect breaker. Record the value on the Data Sheet.

Switch the Iq Data unit to display $I_{A}, I_{B}$, and $I_{C}$. Record the displayed values on the Data Sheet.

The phase currents measured by the IQ Data unit should be approximately the same as the measurement of the same current by the clamp-on ammeter. For each phase, compare the 2 measurements. If they differ by more than 10\%, stop the test and notify the Test Director. (Since there is no load on the PDP, the currents should be 0. )

Open the Main Disconnect breaker (OFF position). 


\begin{tabular}{|c|c|c|c|c|c|}
\hline \multicolumn{6}{|c|}{ DATA SHEET WHC-SD-W320-ATP-005 } \\
\hline \multirow{2}{*}{ STEP } & \multirow{2}{*}{ PERFORM/VERIFY } & \multirow{2}{*}{\multicolumn{2}{|c|}{ MEASUREMENT }} & & \\
\hline & & & & INITIAL & DATE \\
\hline \multirow{3}{*}{8.4 .4} & 1st measurement of PT voltage $=$ & 120,3 & volts & I & $8 / 3 / 46$ \\
\hline & 2nd measurement of PT voltage $=$ & 120.1 & volts & 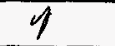 & $8 / 3 / 16$ \\
\hline & $3 r d$ measurement of PT voltage $=$ & 120.2 & volts & $\mathcal{1}$ & $8 / 3 / 46$ \\
\hline \multirow{3}{*}{8.4 .14} & IQ DATA $V_{A B}=$ & 480 & voits & 1 & $8 / 3 / 46$ \\
\hline & IQ DATA $V_{B C}=$ & 481 & voits & 1 & $8 / 3 / 96$ \\
\hline & IQ DATA $V_{C A}=$ & 3477 & volts & of & $8 / 3 / 16$ \\
\hline \multirow{3}{*}{8.4 .15} & VOM $V_{A B}=$ & 481 & volts & $\not$ & $r / 3 / 96$ \\
\hline & VOM $V_{B C}=$ & 482 & volts & O) & $r / 3 / 46$ \\
\hline & Soo Excopting & 479 & volts & $\mathscr{P}$ & $8 / 3 / 96$ \\
\hline \multirow{3}{*}{8.4 .17} & IQ DATA $V_{A N}=$ & $27 \gamma$ & volts & 1 & $8 / 3 / 96$ \\
\hline & 10 DATA $V_{\mathrm{BN}}=$ & 279 & volts & 1 & $8 / 3 / 96$ \\
\hline & IQ DATA $V_{\mathrm{CN}}=$ & 278 & volts & $y$ & $8 / 3 / 46$ \\
\hline \multirow{3}{*}{8.4 .18} & VOM $V_{A N}=$ & $27 \%$ & volts & 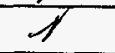 & $8 / 3 / 46$ \\
\hline & VOM $V_{B H}=$. & 280 & volts & of & $8 / 3 / 96$ \\
\hline & VOM $V_{C H}=$ & 278 & volts & 1 & $8 / 3 / 2 b$ \\
\hline 8.5 .1 & Ammeter $\mathrm{A} \mathrm{ph}=$ & .2 & amps & If & $8 / 3 / 8$ \\
\hline 8.5 .2 & Ammeter $\mathrm{B}$ ph $=$ & .2 & amps & $\Rightarrow$ & $8 / 3 / 2$ \\
\hline 8.5 .3 & Ammeter $\mathrm{C}$ ph $=$ & .3 & amps & 4 & $8 / 3 / 56$ \\
\hline \multirow{3}{*}{8.5 .4} & IQ DATA A ph $=$ & 0 & amps & 7 & $8 / 3 / 46$ \\
\hline & IQ DATA B ph $=$ & $\theta$ & amps & 1 & $8 / 3 / 26$ \\
\hline & IQ DATA C ph $=$ & 0 & amps & 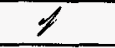 & $8 / 3 / 46$ \\
\hline
\end{tabular}


$\dot{9} \cdot \quad \because \quad$ tést COMPLETION FINAL EQUiPMENT LINEUP

Upon completion of the testing steps, the positions of circuit breakers and disconnect switches used in this test should be as shown in the following table. If any of the devices are not in the required position, notify the Test Director. The Test Director will determine the appropriate action.

\begin{tabular}{|c|c|c|c|}
\hline LOCATION & PERFORM/VERIFY & INITIAL & DATE \\
\hline PDP & $\begin{array}{l}\text { Breaker Electrical Equipment Skid - } \\
\text { Building 241-AY-51: OFF }\end{array}$ & & $8 / 3 / a_{6}$ \\
\hline PDP & Breaker IT-FBI: OFF & 1 & $8 / 2 / 96$ \\
\hline PDP & Breaker HPPT-FBl: OFF & 1 & $8 / 3 / 56$ \\
\hline PDP & Breaker SBT-FBl: OFF & 4 & $8 / 3 / 46$ \\
\hline PDP & AIT (3) Spare breakers: OFF & 1 & $8 / 3 / 86$ \\
\hline PDP & Main Disconnect Breaker: OFF & 1 & $8 / 3 / 16$ \\
\hline
\end{tabular}




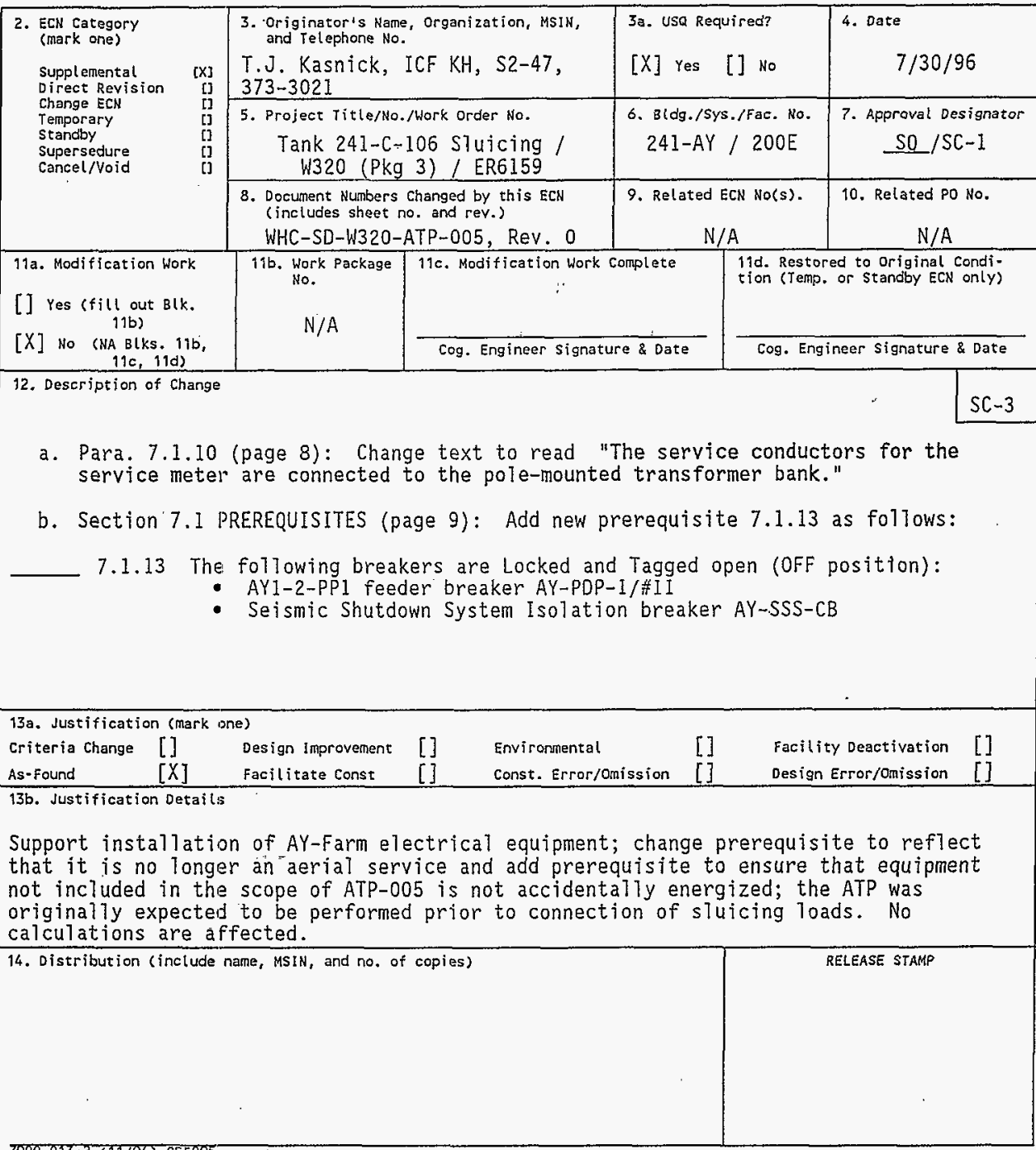

$$
\begin{gathered}
-16 \text { - WHC-SD-W320-ATR-OOS } \\
\text { CAS } 9110196
\end{gathered}
$$




\section{UNREVIEWED SAFETY QUESTION SCREEINING/DETERIMINATION FORM}

(Per WHC-IP-0842)

Page 1 of 5

USO Tracking No.

TF-96-0549

Rev. 0

AREA: [X] East [] West [] General

$\begin{array}{llll}\text { Facility: [] 242-A } & \text { [] DST } & \text { [] SST } & \text { [] LERF } \\ & \text { [X] Aging Waste } & \text { [] Other }\end{array}$

ECN No. $W-320-408$

PCA No.

Work Pkg No.

Other (Specify)

TITLE: Tank 241-C-106 Sluicing System: Add prerequisite to ATP-005

Description of the Proposed Activity/REPORTABLE OCCURRENCE or PIAB:

This ECN changes a prerequisite to reflect that this is no longer an aerial service and adds a prerequisite to ATP-005 to ensure that equipment not included within the scope of ATP-005 is not accidentally energized.

Introduction:

Project W-320 has been established to provide the equipment and components necessary to remove and transporti radioactive and chemical sludge from single-shel1 tank 241-C-106 to double-shel1 tank 241-AY-102. To meet the goals of the project, a Waste Retrieval S7uicing System (WRSS) that uses past-practice sluicing technology has been designed and is being installed. ATPs have been prepared to demonstrate that the Project W320 equipment functions as required by the Project design criteria. ATP-005 tests that the upstream portion of the AY-Farm Electrical Distribution System; ATP-007 tests the downstream portion of the AY-Farm Electrical Distribution System. ATP-005 and ATP-007 do not include the aperation of end-use components (loads) supplied from the distribution system. Performance of ATP-005 and ATP-007 do not have the potential to affect the safe operation of existing AY-Farm safety equipment or any other equipment associated with Tank AY-102. The change associated with this ECN only changes a prerequisite to reflect that this is no ionger an aerial service and adds a new prerequisite for safe performance of ATP-005, and does not change the function of any system. There are no impacts to safety for Tank 241-AY-102.

\section{Scope:}

The revised prerequisite reflects that the electrical service is not an aerial service and the new prerequisite will add equipment and personnel protection to ATP-005 by locking and tagging two Project W320 circuit breakers that will serve future loads.

Authorization Basis:

WHC-SD-WM-ISB-001, Ch 6, Rev. 0, Hanford Site Tank Farm Facilitites Interim Safety Basis WHC-SD-WM-OSR-004, Rev. 1, Aging Waste Facility Interim Operational Safety Requirements WHC-SD-WM-SAD-024, Rev. 0, Safety Assessment for Tank 241-C-106 Waste Retrieva7, Project $W-320$

WHC-SD-WM-PSE-010, Riev. 2, Preliminary Safety Evaluation for 241-C-106 Waste Retrieval, Project $W-320$

A-6001-203 (06/96) GEF289

$$
\begin{gathered}
-17 \text { - WHC-SD-W320-ATR- } \\
\text { REV.O } \\
\text { GAS } \% 10196
\end{gathered}
$$




\begin{tabular}{|l|l|}
\hline \multirow{2}{*}{$\begin{array}{c}\text { UNREVIEWED SAFETY QUESTION SCREENING/DETERMINATION FORM } \\
\text { (Continued) }\end{array}$} & $\begin{array}{c}\text { Page } 2 \text { of } 5 \\
\text { USO Tracking No. } \\
\text { TF-96-0549 }\end{array}$ \\
\cline { 2 - 3 } & Rev. 0 \\
\hline
\end{tabular}

WHC-SD-WM-SEL-033, Rev. 2A, Interim Safety Equipment List for 241-C-106 Waste Retrieval, Project $W-320$

WHC-IP-0954, Rev. 4., Tank Farm Interim Operational Safety Requirements Compliance Implementation Plan

Conclusion:

These changes are within the bounds of the existing Authorization Basis and USQ screening TF-96-022\%, Rev. 0. No unreviewed safety question is created by this ECN.

References

USQ screening TF-96-0222, Rev. 0 .

SD-HS-SAR-010, Rev. 1 \& 2, Aging Waste Facility Safety Analysis Report

OSD-T-151-0007, Rev H-17, Operating Specifications for the 241-AN, $A P, A W, A Y, A Z$, and sY Tank Farms

OSD-T-151-0030, Rev B-20, Operating Specifications for Watch List Tanks

Letter 9456832, Justificätion for Continued Operation - Dome Loading

USO Screening:

A. Does the PROPOSED ACTIVITY represent a change to the facility as described in the AUTHORIZATION BASIS?
[X] No
[] Yes
[] N/A

Basis: The level of detail of this change is outside the scope of the Authorization Basis Documents and reference documents, and does not change the facility as described in the Authorization Basis Documents. The revision of the prerequisite and the addition of a prerequisite to ATP-005 is already bounded by USQ Screening $T F-96-0222$, which concluded that there is no unreviewed safety question for performance of ATP-007; refer to USQ screening TF-96-0222 Rev. 0.

B. Does the PROPOSED ACTIVITY represent a change to procedures as described in the AUTHORIZATION BASIS?

[X] No [] Yes [] N/A

Basis: The only procedure affected by this ECN is the new ATP WHC-SD-W320-ATP-005. This is not a change to procedures described in the Authorization Basis Document WHC-SD-WM-ISB-001 or reference document WHC-SD-WM-0SR-004. 
Rev. 0

C. Does the test or experiment represent a test or experiment not described in the AUTHORIZATION BASIS documentation?
[X] No
[] Yes
[] N/A

Basis: ATP-005 tests W320 equipment to demonstrate that a portion of the AY-Farm Electrical Distribution System functions as required by the design criteria. This change only revises an existing prerequisite and adds a new prerequisite for performance of ATP-005. This change does not alter the purpose of the ATP.

D. Does the PROPOSED ACTIVITY or REPORTABLE OCCURRENCE, impact:

- OSRs or IOSRs?

- Approved IOSR Compliance Implementation Plan?
[X] No
[] Yes
[] $N / A$

Basis: These changes do not impact OSRs/IOSRs nor the approved Compliance Implementation Plan.

E. Does the REPORTABLE OCCURRENCE or PIAB involve analytical errors, omissions, and/or deficiencies in the AUTHORIZATION BASIS?
[] $\mathrm{N}$
[] Yes
[X] N/A

Basis: These changes are not a reportable occurrence or PIAB.

USQE No. 1 T.J. Kasnick

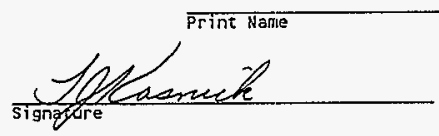

USOE No. 2 John W. Bailey

print Name

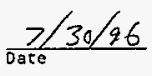

signature

Date

IF "YES", USOE CONTINUE WITH DETERMINATION BELOW

USQ DETERMINATION:

1. Could the PROPOSED ACTIVITY or USO ISSUE significantly increase the frequency of occurrence of an accident previously evaluated in the AUTHORIZATION BASIS?

[] No [] Yes/Maybe

Basis:

2. Could the PROPOSED ACTIVITY or USQ Issue significantly increase the consequences of an accident previously evaluated in the AUTHORIZATION BASIS?

[] No [] Yes/Maybe 
Rev. 0

Basis:

3. Could the PROPOSED ACTIVITY or USO ISSUE significantly increase the frequency of occurrence of a malfunction of EQUIPMENT IMPORTANT TO SAFETY previously evaluated in the AUTHORIZATION BASIS?

[] No [] Yes/Maybe

Basis:

4. Could the PROPOSED ACTIVITY or USO ISSUE significantly increase the consequences of a malfunction of EOUIPMENT IMPORTANT TO SAFETY previously evaluated in the AUTHORIZATION BASIS?

[] No [] Yes/Maybe

Basis:

5. Could the PROPOSED ACTIVITY or USQ ISSUE create the possibility of an accident of a different type than any previously evaluated in the AUTHORIZATION BASIS?

[] No [] Yes/Maybe

Basis:

6. Could the PROPOSED ACTIVITY or USQ ISSUE create the possibility of a malfunction of EQUIPMENT IMPORTANT TO SAFETY of a different type than any previously evaluated in the AUTHORIZATION BASIS?

[] No [] Yes/Maybe

Basis:

7. Could the PROPOSED ACTIVITY or USQ ISSUE reduce the margin of safety for any OSR/IOSR as defined in the AUTHORIZATION BASIS?

[] No [] Yes/Maybe

Basis:

8. Does the PROPOSED ACTIVITY or USO ISSUE require a new or revised OSR/IOSR lincluding compensatory measures required by a Compliance (mplementation Plan)?

[] No [] Yes/Maybe

Basis: 


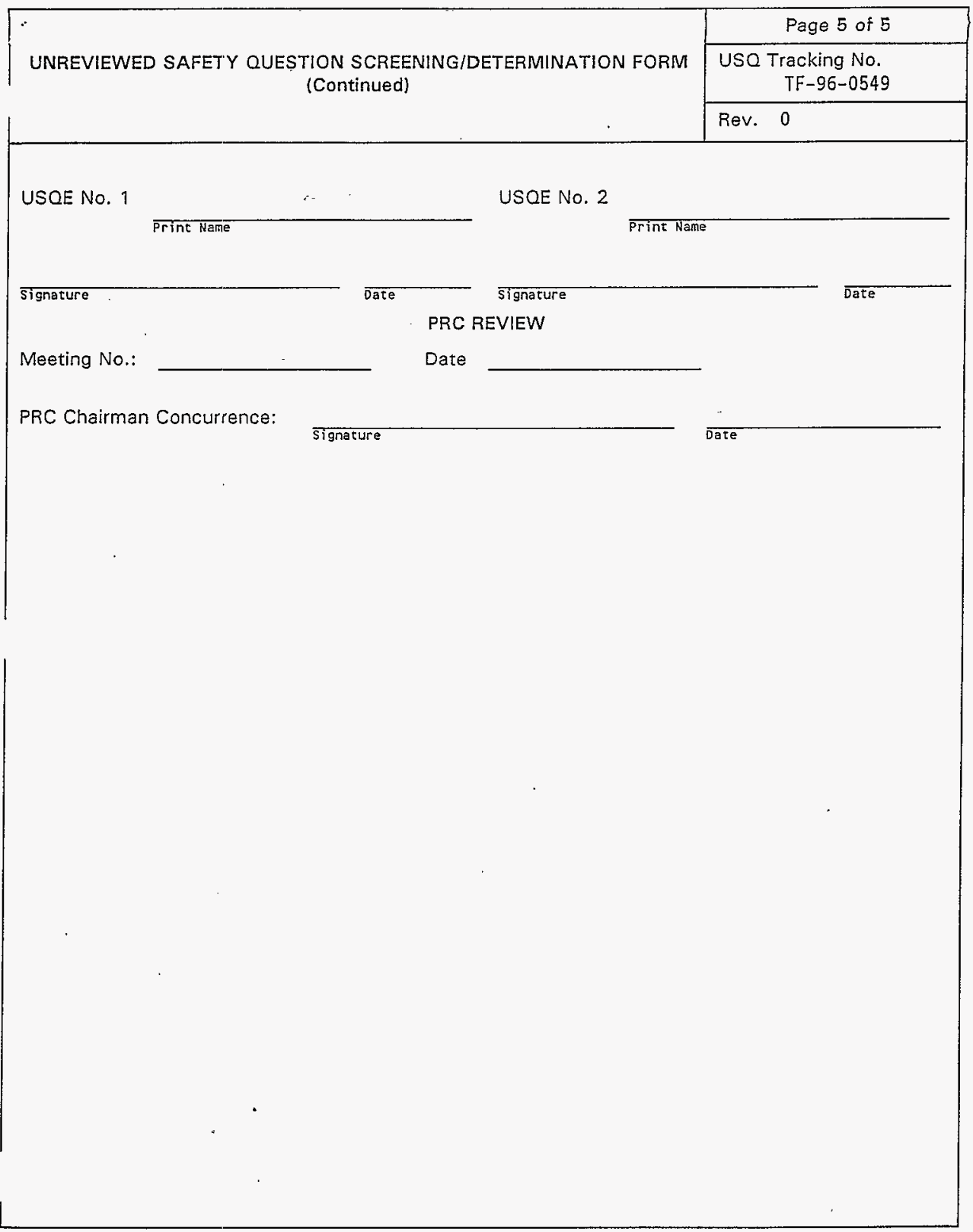


SUPPORTING DOCUMENT ENCODE SHEET - IT CO *O EQ

Document Number

Revision Number

Release Date

Design Authority

Releasing EDT

Author

Title

Project Number

Classification

Organization Code

Distribution Limit

Total Page Count

Release 5ta-Clerk ID

Cross Reference

Alternate Document No.

TTN Number

Key Words
$1 * S D-\underline{W 2 a A T R-O 04} *$

${ }^{*}=\frac{0}{91 / 8}={ }^{*}$

$21 * 12 A C$

.*E DT-6e $\leq 0 \$ 59 *$

5* SuMmons GA

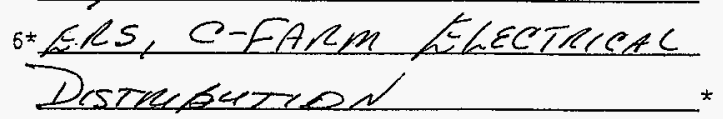

$8^{*}$

$11 \div$

$13 * 273530$

$23^{*}$

$32^{*}$

$50 *$

$77^{*}$

$85 *$

$180 \div 181 *$

$250 \div 251 *$

$250 * 251 *$.

$250 \div 251 *$

$250 * 251 *$

$250 * 251 *$

$250 * 251 *$

$250 * 251 *$

$* E N D *$ : 
SUPPORTING DOCUMENT ENCODE SHEET - IT CO *O EQ

Document Number

Revision Number

Release Date

Desian Authority

Releasing EDT

Author

Title

Project Number

Classification

Organization Code

Distribution Limit

Total Page Count

Release Sie-Clerk ID

Cross Reference

ATternate Document No.

ETN Number

Key Words

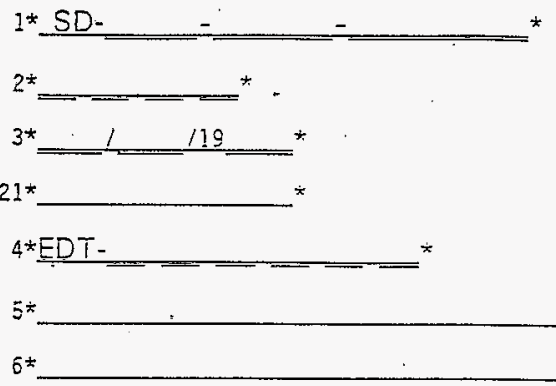

$8 *$

11*

$13 *$

$23^{\frac{1}{x}}$

$3 ? \times$

$59 \times \ldots$

$77 \pi$

$\widehat{s} \div$

$180 \div 181 *$

$250 * 251 *$

$250 \div 251 *$

$250 \times 251 *$

$250 \div 251^{\star}$

$250^{\circ}+251 *$

$250 * 251 *$

$250 * 25 I *$ *END*: 